\title{
Role of autophagy in drug induced liver injury
}

\author{
Tim Brecklinghaus ${ }^{1}$ (D)
}

Received: 17 August 2020 / Accepted: 18 August 2020 / Published online: 27 August 2020

(c) The Author(s) 2020

Recently, Wandrer and colleagues published a study about the interaction of endoplasmic reticulum (ER) stress and autophagy and its relevance for hepatotoxicity (Wandrer et al. 2020). For this purpose, they used the iodinated benzofurane derivative amiodarone as a model compound. Amiodarone is known to induce steatohepatitis (Lewis et al. 1989; Vassallo and Trohman 2007) of which a relatively high fraction progresses to liver cirrhosis (Rigas 1989; Farrell 2002; Raja et al. 2009). Amiodarone mediated DILI has been reported to progress despite of discontinuation of the drug, possibly because of the very long half-life in the liver (Lewis et al. 1989; Vassallo and Trohman 2007; Chang et al. 1999; Brien et al. 1987). In the present study, Wandrer and colleagues demonstrated that patients treated with amiodarone had higher serum levels of the apoptosis marker caspase-cleaved keratin-18 compared to individuals not treated with amiodarone. Next, they demonstrated that incubation of hepatocytes with amiodarone induced lipid accumulation and ER-stress (Wandrer et al. 2020). Interestingly, co-incubation of amiodarone with the autophagy inhibitor chloroquine increased amiodarone-induced toxicity. Also, in ATG5- or ATG7-deficient hepatocytes amiodarone-triggered toxicity was increased.

Drug-induced liver injury represents a major research field in toxicology (Godoy et al. 2013; Leist et al. 2017; Jansen et al. 2017). Research aims at a better understanding of DILI mechanisms (Albrecht et al. 2019; Vartak et al. 2016; Reif et al. 2017) and the establishment of in vitro (Gu et al. 2018; Grinberg et al. 2014, 2018; Frey et al. 2014) and in silico methods (Ghallab et al. 2016, 2019; Hoehme et al. 2010). Nevertheless, still relatively little is known how autophagy modifies DILI and if in vitro findings are also relevant to the in vivo situation. Wandrer and colleagues are to be congratulated, because they not only demonstrate

Tim Brecklinghaus

brecklinghaus@ifado.de

1 Leibniz Research Centre for Working Environment and Human Factors, Ardeystr. 67, 44139 Dortmund, Germany that autophagy induction ameliorates amiodarone mediated hepatotoxicity but also study human in vivo relevance by analysis of the apoptosis marker keratin-18 in serum.

Funding Open Access funding provided by Projekt DEAL.

\section{Compliance with ethical standards}

Conflict of interest The author declares that he has no conflict of interest.

Open Access This article is licensed under a Creative Commons Attribution 4.0 International License, which permits use, sharing, adaptation, distribution and reproduction in any medium or format, as long as you give appropriate credit to the original author(s) and the source, provide a link to the Creative Commons licence, and indicate if changes were made. The images or other third party material in this article are included in the article's Creative Commons licence, unless indicated otherwise in a credit line to the material. If material is not included in the article's Creative Commons licence and your intended use is not permitted by statutory regulation or exceeds the permitted use, you will need to obtain permission directly from the copyright holder. To view a copy of this licence, visit http://creativecommons.org/licenses/by/4.0/.

\section{References}

Albrecht W, Kappenberg F, Brecklinghaus T et al (2019) Prediction of human drug-induced liver injury (DILI) in relation to oral doses and blood concentrations. Arch Toxicol 93(6):1609-1637. https ://doi.org/10.1007/s00204-019-02492-9

Brien JF, Jimmo S, Brennan FJ et al (1987) Distribution of amiodarone and its metabolite, desethylamiodarone, in human tissues. Can J Physiol Pharmacol 65(3):360-364. https://doi.org/10.1139/ y87-062

Chang CC, Petrelli M, Tomashefski JF et al (1999) Severe intrahepatic cholestasis caused by amiodarone toxicity after withdrawal of the drug: a case report and review of the literature. Arch Pathol Lab Med 123(3):251-256. https://doi.org/10.1043/00039985(1999)123<0251:SICCBA>2.0.CO;2

Farrell GC (2002) Drugs and steatohepatitis. Semin Liver Dis 22(2):185-194. https://doi.org/10.1055/s-2002-30106

Frey O, Misun PM, Fluri DA, Hengstler JG, Hierlemann A (2014) Reconfigurable microfluidic hanging drop network for multitissue interaction and analysis. Nat Commun 5:4250. https://doi. org/10.1038/ncomms5250 
Ghallab A, Cellière G, Henkel SG et al (2016) Model-guided identification of a therapeutic strategy to reduce hyperammonemia in liver diseases. J Hepatol 64(4):860-871. https://doi.org/10.1016/j. jhep.2015.11.018

Ghallab A, Hofmann U, Sezgin S et al (2019) Bile microinfarcts in cholestasis are initiated by rupture of the apical hepatocyte membrane and cause shunting of bile to sinusoidal blood. Hepatology 69(2):666-683. https://doi.org/10.1002/hep.30213

Godoy P, Hewitt NJ, Albrecht U et al (2013) Recent advances in 2D and $3 \mathrm{D}$ in vitro systems using primary hepatocytes, alternative hepatocyte sources and non-parenchymal liver cells and their use in investigating mechanisms of hepatotoxicity, cell signaling and ADME. Arch Toxicol 87(8):1315-1530. https://doi.org/10.1007/ s00204-013-1078-5

Grinberg M, Stöber RM, Edlund K et al (2014) Toxicogenomics directory of chemically exposed human hepatocytes. Arch Toxicol 88(12):2261-2287. https://doi.org/10.1007/s00204-014-1400-x

Grinberg M, Stöber RM, Albrecht W et al (2018) Toxicogenomics directory of rat hepatotoxicants in vivo and in cultivated hepatocytes. Arch Toxicol 92(12):3517-3533. https://doi.org/10.1007/ s00204-018-2352-3

Gu X, Albrecht W, Edlund K et al (2018) Relevance of the incubation period in cytotoxicity testing with primary human hepatocytes. Arch Toxicol 92(12):3505-3515. https://doi.org/10.1007/s0020 4-018-2302-0

Hoehme S, Brulport M, Bauer A et al (2010) Prediction and validation of cell alignment along microvessels as order principle to restore tissue architecture in liver regeneration. Proc Natl Acad Sci U S A 107(23):10371-10376. https://doi.org/10.1073/pnas.0909374107

Jansen PL, Ghallab A, Vartak N et al (2017) The ascending pathophysiology of cholestatic liver disease. Hepatology 65(2):722-738. https://doi.org/10.1002/hep.28965
Leist M, Ghallab A, Graepel R et al (2017) Adverse outcome pathways: opportunities, limitations and open questions. Arch Toxicol 91(11):3477-3505. https://doi.org/10.1007/s00204-017-2045-3

Lewis JH, Ranard RC, Caruso A et al (1989) Amiodarone hepatotoxicity: prevalence and clinicopathologic correlations among 104 patients. Hepatology 9(5):679-685. https://doi.org/10.1002/ hep. 1840090504

Raja K, Thung SN, Fiel MI et al (2009) Drug-induced steatohepatitis leading to cirrhosis: long-term toxicity of amiodarone use. Semin Liver Dis 29(4):423-428. https://doi.org/10.1055/s-0029-1240011

Reif R, Ghallab A, Beattie L et al (2017) In vivo imaging of systemic transport and elimination of xenobiotics and endogenous molecules in mice. Arch Toxicol 91(3):1335-1352. https://doi. org/10.1007/s00204-016-1906-5

Rigas B (1989) The evolving spectrum of amiodarone hepatotoxicity. Hepatology 10(1):116-117. https://doi.org/10.1002/hep.18401 00123

Vartak N, Damle-Vartak A, Richter B et al (2016) Cholestasis-induced adaptive remodeling of interlobular bile ducts. Hepatology 63(3):951-964. https://doi.org/10.1002/hep.28373

Vassallo P, Trohman RG (2007) Prescribing amiodarone: an evidencebased review of clinical indications. JAMA 298(11):1312-1322. https://doi.org/10.1001/jama.298.11.1312

Wandrer F, Frangež Ž, Liebig S et al (2020) Autophagy alleviates amiodarone-induced hepatotoxicity. Arch Toxicol. https://doi. org/10.1007/s00204-020-02837-9 (online ahead of print)

Publisher's Note Springer Nature remains neutral with regard to jurisdictional claims in published maps and institutional affiliations. 